\title{
ENHANCEMENT OF PROPAGATION OF MYCOPLASMA HYOPNEUMONIAE BY CULTURE IN A BIPHASIC MEDIUM
}

\author{
O. FISCHER \\ Veterinary Research Institute, 61242 Brno
}

Received June 20, 1995

\begin{abstract}
Fischer, O.: Enhancement of Propagation of Mycoplasma hyopneumoniae by Culture in a Biphasic Medium. Acta vet. Brno, 1995, 64:243-247.

Mycoplasma hyopneumoniae (strain $\mathrm{J}$ ) was propagated in a liquid and a biphasic media. The solid phase of the biphasic medium was obtained by the addition of $1.9 \%$ or $0.19 \%$ of agar to the liquid medium. Compared with the liquid medium, a more rapid propagation of mycoplasmas was observed in the biphasic medium after two weeks of incubation. After three weeks of incubation in the liquid and the biphasic medium containing $0.19 \%$ of agar in the solid phase, the numbers of mycoplasmas rose 2.7 fold and 4.7 fold, respectively. The biphasic medium, simulating partly the environment of the porcine respiratory tract, supported better the propagation of $M$. hyopneumoniae than the liquid medium. The biphasic medium containing $0.19 \%$ of agar in the solid phase should be preferred when a mass of Mycoplasma cells is to be obtained.
\end{abstract}

Porcine enzootic pneumonia, culture media, biomass

The causal agent of porcine enzootic pneumonia Mycoplasma hyopneumoniae ranks with Mycoplasma species which are difficult to propagate (Friis 1975, 1979). On solid media, this species does not form the "fried eggs" colonies typical of a majority of mycoplasmas, but rather small, dispersed bodies resembling poppy-seeds. The propagation in liquid media is very slow, taking several weeks.

Larger amounts of Mycoplasma cells can be obtained only by gradually increasing the volume of the culture medium (Kuksa et al. 1987).

M. hyopneumoniae lives on the surface of porcine respiratory mucosae (Meyling 1971; Kobisch et al. 1993). The mucus of the respiratory tract protects $M$. hyopneumoniae cells from drying in the environment thus supporting the spread of porcine enzootic pneumonia by droplet infection (Good win 1972; Friis 1973). As a typical mucosal pathogenic agent, $M$. hyopneumoniae is adapted to an environment which is more viscous than are the conventional liquid media used for its culture in vitro.

A biphasic culture medium, simulating partly the conditions prevailing in the porcine respiratory tract, was used to provide more favourable conditions for the culture of $M$. hyopneumoniae in vitro.

\section{Materials and Methods}

The strain J of Mycoplasma hyopneumoniae (type strain NCTC 10110, ATCC 25934) was obtained from the Collection of Animal Pathogenic Microorganisms, Brno (CAPM M-38).The biphasic culture medium consisted of solid and liquid phases.

Liquid phase

The medium FF (Friis, 1971) was modified as follows:

Saline A: $160 \mathrm{~g} \mathrm{NaCl}, 8 \mathrm{~g} \mathrm{KCl}, 2 \mathrm{~g} \mathrm{MgSO}_{4} \cdot 7 \mathrm{H}_{2} \mathrm{O}, 2 \mathrm{~g} \mathrm{MgCl}_{2} \cdot 6 \mathrm{H}_{2} \mathrm{O}$, and $2.8 \mathrm{~g}$ anhydrous $\mathrm{CaCl}_{2}$ were dissolvẹ in $1 \mathrm{~L}$ bidistilled water.

Saline $\mathrm{B}: 3 \mathrm{~g} \mathrm{Na}_{2} \mathrm{HPO}_{4} \cdot 12 \mathrm{H}_{2} \mathrm{O}$ and $1.2 \mathrm{~g} \mathrm{KH}_{2} \mathrm{PO}_{4}$ were dissolved in $1 \mathrm{~L}$ bidistilled water. 
The stock salines A and B were diluted by adding to $7.5 \mathrm{ml} 125 \mathrm{ml}$ and $17.5 \mathrm{ml}$ bidistilled water, respectively. Then the salines were mixed and $2.6 \mathrm{~g}$ Mycoplasma Broth Base (Oxoid) and $2.5 \mathrm{~g}$ Brain Heart Infusion (Oxoid) were added. The mixture was completed with $225 \mathrm{ml}$ bidistilled water and autoclaved at $121^{\circ} \mathrm{C}$ and $110 \mathrm{kPa}$ for $30 \mathrm{~min}$. After cooling, $78 \mathrm{ml}$ horse blood serum, $18 \mathrm{ml}$ yeast extract, $5 \mathrm{ml} \mathrm{10 \%}(\mathrm{w} / \mathrm{v})$ glucose and $1 \mathrm{ml} 5 \%(\mathrm{w} / \mathrm{v})$ thalium acetate solutions and $200 \mathrm{mg}$ ampicillin were added. $\mathrm{pH}$ was adjusted to 7.6.

\section{Solid phase}

The liquid medium FF was completed with 4.5 or $0.45 \mathrm{~g}$ Noble agar (Difco) before autoclaving, supplemented with the same components as the liquid medium $\mathrm{FF}$ after autoclaving and cooling to $50^{\circ} \mathrm{C}$ and poured into culture vessels. The agar concentrations in the solid media were $1.9 \%$ and $0.19 \%$, respectively.

The solid medium for counting $M$. hyopneumoniae bodies was prepared by dissolving $4 \mathrm{~g}$ PPLO agar (Difco) in $105 \mathrm{ml}$ bidistilled water. The medium was completed with $30 \mathrm{ml}$ horse blood serum, $15 \mathrm{ml}$ yeast extract, $100 \mathrm{mg}$ ampicillin and $0.75 \mathrm{ml} 5 \%$ thalium acetate after autoclaving and cooling to $50^{\circ} \mathrm{C}$. The hot medium was poured into plastic $60 \mathrm{~mm}$ Petri dishes to form a 2-mm layer.

\section{Comparison of $M$. hyopneumoniae propagation in liquid and biphasic media}

\section{Experiment 1}

Forty $\mathrm{ml}$ of the liquid medium or forty $\mathrm{ml}$ of the hot solid phase containing $1.9 \%$ agar were poured into $100-\mathrm{ml}$ glass bottles. The agar was left to solidify in slant position (Fig. 1). After warming to $37^{\circ} \mathrm{C}$, the media were inoculated with $5 \mathrm{ml}$ of a $M$. hyopneumoniae suspension containing $2.9 \times 10^{5}$ bodies per $1 \mathrm{ml}$ and the cultures were incubated at $37^{\circ} \mathrm{C}$. Forty $\mathrm{ml}$ of fresh liquid medium were added after 3 days incubation and $0.2 \mathrm{ml}$ of the suspension were collected and inoculated onto the solid medium for the counting of $M$. hyopneumoniae bodies after another 14 days.

\section{Experiment 2}

Forty $\mathrm{ml}$ of the liquid medium or forty $\mathrm{ml}$ of the hot solid phase containing $0.19 \%$ agar were poured into $100-\mathrm{ml}$ glass bottles. The agar was left to solidify in slant position (Fig. 1). After warming to $37^{\circ} \mathrm{C}$, the media were inoculated with $5 \mathrm{ml}$ of a $M$. hyopneumoniae suspension containing $1.2 \times 10^{5}$ bodies per $1 \mathrm{ml}$ and the cultures were incubated at $37^{\circ} \mathrm{C}$. Forty-five $\mathrm{ml}$ of fresh liquid medium were added after 3 days of incubation and $0.2 \mathrm{ml}$ to 0.4 $\mathrm{ml}$ of the suspension were collected and inoculated onto the solid medium for the counting of $M$. hyopneumoniae bodies at weekly intervals during the three-week incubation period. The experiment was repeated twice.

\section{Counting of $M$. hyopneumoniae bodies}

A known volume $(0.2 \mathrm{ml}$ to $0.4 \mathrm{ml})$ of a well shaken Mycoplasma suspension was applied onto the solid medium in a 60-mm Petri dish to cover the whole surface of the medium. The dishes were left to stand for $30 \mathrm{~min}$ and then incubated at $37^{\circ} \mathrm{C}$ for 3 days.

$M$. hyopneumoniae bodies were counted at 10 randomly selected sites at the magnification $630 \mathrm{x}$ using an eyepiece screen.

\section{Sterility checks}

A sample of the suspension was collected at each opening of a culture vessel, inoculated onto blood agar and incubated at $37^{\circ} \mathrm{C}$. Attention was paid to Mycoplasma colonies suggestive of contamination at the counting of the M. hyopneumoniae bodies.

\section{Results}

Mycoplasma hyopneumoniae propagated in both the liquid and the biphasic media and $M$. hyopneumoniae bodies resembling dispersed poppy-seeds were observed with a light microscope after reinoculation onto the solid medium.

\section{Experiment 1}

The number of $M$. hyopneumoniae bodies increased 1.5 fold (from $2.9 \times 10^{5}$ bodies per 1 $\mathrm{ml}$ of inoculum to $4.5 \times 10^{5}$ bodies per $1 \mathrm{ml}, \mathrm{P}<0.01$ ) and 4.8 fold (to $1.4 \times 10^{6}$ bodies per $1 \mathrm{ml}, \mathrm{P}<0.01$ ) during the 14-day incubation in the liquid and the biphasic media, respectively. The medium containing $1.9 \%$ agar disintegrated when the culture vessels were shaken, but large fragments of solid agar remained in the liquid phase. 


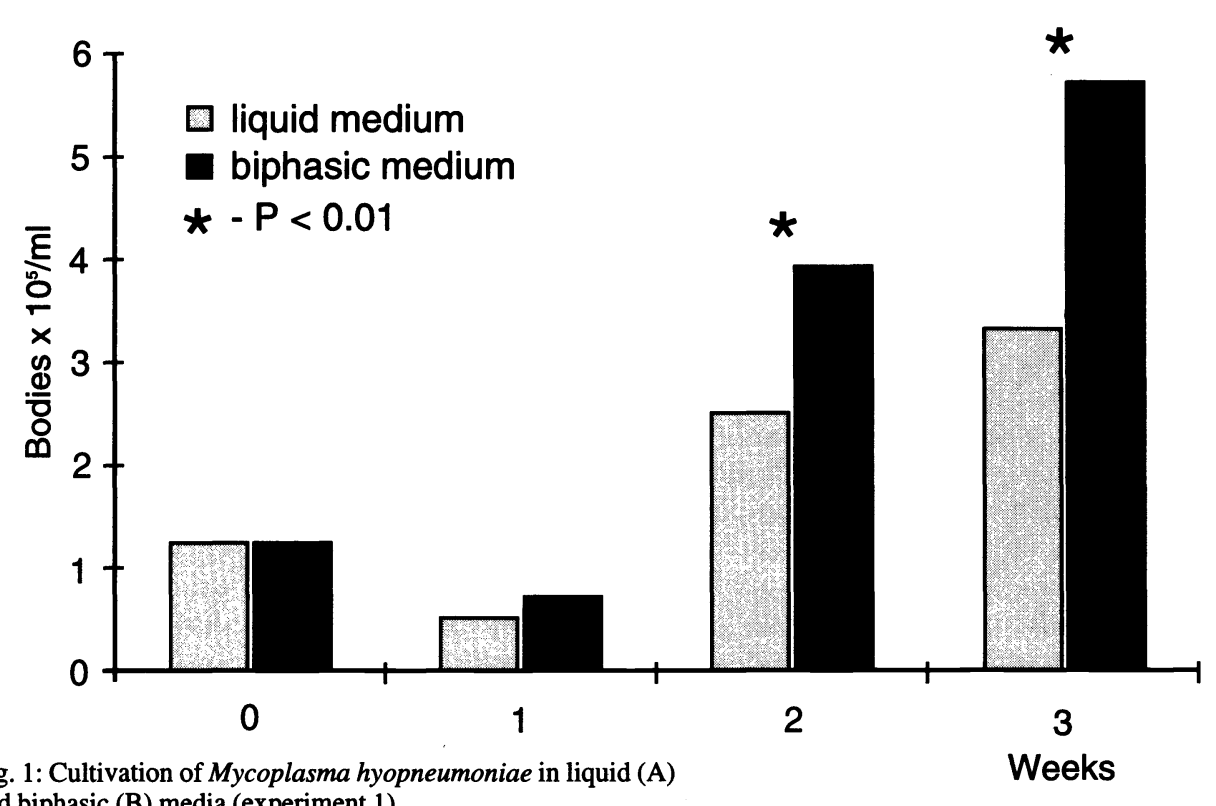

and biphasic (B) media (experiment 1 ).

\section{Experiment 2}

Mean values obtained in three experiments made with various batches of the media are shown in Fig. 2 . The numbers of $M$. hyopneumoniae bodies decreased both in the liquid and the biphasic media and the difference in counts of $M$. hyopneumoniae bodies between the two media was non-significant $(P>0.05)$ by the end of the first week of incubation.

During the second week, the numbers of mycoplasmas rose twofold (from $1.2 \times 10^{5}$ to $2.5 \times 10^{5}$ bodies per $1 \mathrm{ml}, \mathrm{P}<0.01$ ) and threefold (to $3.9 \times 10^{5}$ bodies per $1 \mathrm{ml}, \mathrm{P}<0.01$ ) in the liquid and the biphasic media, respectively.

Further 2.7 fold $\left(3.3 \times 10^{5}\right.$ bodies per $\left.1 \mathrm{ml}, \mathrm{P}<0.01\right)$ and 4.7 fold $\left(5.7 \times 10^{5}\right.$ bodies per $1 \mathrm{ml}, \mathrm{P}<0.01$ ) increases were recorded after three weeks of incubation in the liquid and the biphasic media, respectively. The $0.19 \%$ agar dissolved almost completely in the liquid medium. No contamination by bacteria or colony-forming Mycoplasma species was demonstrable.

\section{Discussion}

Bruggmann et al. (1977) demonstrated M. hyopneumoniae in frozen lung sections collected from swine suffering from enzootic porcine pneumonia by the immunoperoxidase reaction. $M$. hyopneumoniae cells were visible as reddish brown pleiomorphic spots on the mucosa of the respiratory tract and on the surface of scraped-off epithelial cells.

Zielinski et al. (1990) observed adhesion of M. hyopneumoniae to porcine and human cell cultures. The adhesion to the porcine cells was more intensive. De Bey and Ross (1994) described $M$. hyopneumoniae-induced ciliostasis and loss of ciliae in cells of organ cultures prepared from porcine tracheal rings.

For solid medium either Ionagar No. 2 or Agar-Agar (both from Oxoid Ltd., London) can be used at a concentration $0.8 \%$. Agarose $0.9 \%$ without DEAE-Dextran may be used instead of agar (Friis 1975). 
The culture in a biphasic medium combines the advantages of the liquid and the solid culture media and partly simulates the conditions prevailing in the porcine respiratory tract. While mycoplasmas grown in a liquid medium can adhere only to the glass surface of culture vessels, in a biphasic medium they can first propagate in the nutrient-rich agar and the continuing growth is supported by the addition of fresh liquid medium providing further nutrients and diluting metabolic products of mycoplasmas. The semisolid agar swells in the liquid medium and eventually dissolves almost completely. Mycoplasma bodies are thus released into the liquid phase of the medium and can be harvested by washing and the centrifugation. The remains of the undissolved agar area very suitable substrate for the propagation of mycoplasmas.

M. hyopneumoniae propagates slowly in liquid media, fermenting glucose and trehalose, but not saccharose, lactose and mannitol (Bannerman and Nicolet 1971), and can be distinguished from the non-pathogenic, slowly growing and glucose fermenting $M$. flocculare by serological tests (Bölske et al. 1987) or biological assay (Abiven et al. 1990).

Comparative morphologic studies of $M$. hyopneumoniae and $M$. flocculare were made by Hovind-Hougen and Friis (1991). Both the species carried on their surfaces fine, 30 to $100 \mathrm{~nm}$ long hairs, were surrounded by a simple membrane consisting of three layers and propagated by binary fission. The size of the spherical or oval bodies of $M$. hyopneumoniae varied between 0.8 and $2.5 \mu \mathrm{m}$, being within the considerably broader range 0.4 to $4.0 \mu \mathrm{m}$ of $M$. flocculare. Unlike $M$. hyopneumoniae, $M$. flocculare formed filamentous cords between cells measuring 140 × 30 to $90 \mathrm{~nm}$. However, special microscopic techniques are necessary for the recognition of this difference. Tajima and Yagihashi (1982), Blanchard et al. (1992), Jacques et al. (1992) in their electron microscopic studies of mycoplasmas found $M$. hyopneumoniae apparently lying free in the bronchiolar lumen of pigs, but in close contact with tips of several microvilli. Very fine fibrils, measuring 0.005 $\mu \mathrm{m}$ in diameter and $0.25 \mu \mathrm{m}$ in length, linked mycoplasmas with microvilli or cilia of host cells and interconnected also individual Mycoplasma bodies. Mycoplasmas propagated in a liquid medium lacked the fibrils. The size of the bodies grown in the liquid medium and found in the porcine respiratory tract ranged from 0.4 to $1.2 \mu \mathrm{m}$ and from 0.5 to $1.0 \mu \mathrm{m}$, respectively. While spherical and oval forms prevailed among mycoplasmas propagated in vitro, those observed in vivo among host cell cilia were elongated.

All the media were warmed to $37^{\circ} \mathrm{C}$ prior to inoculation to avoid cold shock.

The modified medium FF has proven effective for the propagation of $M$. hyopneumoniae. Although the counts decreased in the initial phase of incubation due to dilution and death of a part of the inoculum, a marked increase could be recorded after the adaptation of mycoplasmas to the culture conditions in the 2 nd and 3 rd weeks of culture. The experiments were discontinued after two or three weeks of incubation, because the quality of the media decreased owing to the accumulation of toxic metabolic products of mycoplasmas and dead, disintegrating cells after prolonged incubation.

Although a part of the mycoplasma culture adhered to undissolved remains of agar gel upon the harvest, the yield from the propagation in the biphasic medium was higher than that from cultures in liquid media.

\section{Zvýšení schopnosti dělení Mycoplasma hyopneumoniae kultivací ve dvoufázovém mediu}

Mycoplasma hyopneumoniae (kmen J) bylo kultivováno ve dvou typech medií, tekutém a dvoufázovém. Tuhá fáze dvoufázového media byla vytvořena zahuštěním tekutého media 
1,9 nebo $0,19 \%$ agaru. Po dvou týdnech kultivace bylo zaznamenáno vyšši množství mykoplazmat v mediu dvoufázovém než v mediu tekutém.

Po třech týdnech kultivace $s \mathrm{v}$ tekutém mediu zvýšil pocet mykoplazmat $2,7 \times$, zatímco ve dvoufázovém mediu, jehož pevná fáze obsahovala $0,19 \%$ agaru, 4,7x.

Dvoufázové medium, které cástečně napodobuje poměry $\mathrm{v}$ dýchacích cestách prasete, je pro množení $M$. hyopneumoniae vhodnější než medium tekuté.

Pro snadnějši získávání mykoplazmové biomasy je vhodnějši používat dvoufázové medium, jehož tuhá fáze obsahuje $0,19 \%$ agaru.

\section{Acknowledgement}

Skilled technical help of Mr. Petr Lany with the arrangement of the manuscript is highly appreciated.

\section{References}

ABIVEN, P., STRASSER, M., KOBISCH, M., NICOLET, J. 1990: Antibody response of swine experimentally infected with Mycoplasma hyopneumoniae and Mycoplasma flocculare. Zbl. Bakt., Suppl. 20:817-818

BANNERMAN, E. S. N., NICOLET, J. 1971: Isolation and identification of porcine mycoplasma in Switzerland. Schweiz. Arch. Tierheilk. 113:697-710

BLANCHARD, B., VENA, M. M., CAVALIER, A., LE LANNIC, J., GOURANTON, J., KOBISCH, M. 1992: Electron microscopic observation of the respiratory tract of SPF piglets inoculated with Mycoplasma hyopneumoniae. Vet. Microbiol. 30:329-341

BÖLSKE, G., STRANDBERG, M. L., BERGSTRÖM, K., JOHANSSON, K. E. 1987: Species specific antigens of Mycoplasma hyopneumoniae and cross-reactions with other porcine mycoplasmas. Curr. Microbiol. 15:233239

BRUGGMANN, S., ENGBERG, B., EHRENSPERGER, F. 1977: Demonstration of M. suipneumoniae in pig lungs by the enzyme-linked immunoperoxidase technique. Vet. Rec. 101:137

DeBEY, M. C., ROSS, R. F. 1994: Ciliostasis and loss of cilia induced by Mycoplasma hyopneumoniae in porcine tracheal organ cultures. Infect. Immun. 62:5312-5318

FRIIS, N. F. 1971: Mycoplasma cultivated from respiratory tract of Danish pigs. Acta vet. scand. 12:69-79

FRIIS, N. F. 1973: Resistance of porcine mycoplasmas to drying. Acta vet. scand. 14:489-491

FRIIS, N. F. 1975: Some recommendations concerning primary isolation of Mycoplasma suipneumoniae and Mycoplasma flocculare. Nord. Vet.-Med. 27:337-339

FRIIS, N. F. 1979: Selective isolation of slowly growing acidifying mycoplasmas from swine and cattle. Acta vet. scand. 20:607-609

GOODWIN, R. F. W. 1972: The survival of Mycoplasma suipneumoniae in liquid medium, on solid medium and in pneumonic tissue. Res. vet. Sci. 13:203-204

HOVIND-HOUGEN, K., FRIIS, N. F. 1991: Morphological and ultrastructural studies of Mycoplasma flocculare and Mycoplasma hyopneumoniae in vitro. Res. vet. Sci. 51:155-163

JACQUES, M., BLANCHARD, B., FOIRY, B., GIRARD, C., KOBISCH, M. 1992: In vitro colonization of porcine trachea by Mycoplasma hyopneumoniae. Ann. Rech. Vét. 23:239-247

KOBISCH, M., BLANCHARD, B., LE POTIER, M. F. 1993: Mycoplasma hyopneumoniae infection in pigs: duration of the disease and resistance to reinfection. Vet. Res. 24:67-77

KUKSA, F., PLAČKOV, D., SALAJ, J., BUŘILOVÁ, E. 1987: Vývoj antigenů pro sérologickou diagnostiku mykoplazmových infekcí hrabavé drůbeže. Project report. Veterinary Research Institute, Brno, 23 p.

MEYLING, A. 1971: Mycoplasma suipneumoniae and Mycoplasma hyorhinis demonstrated in pneumonic pig lungs by the fluorescent antibody technique. Acta vet. scand. 12:137-141

TAJIMA, M., YAGIHASHI, T. 1982: Interaction of Mycoplasma hyopneumoniae with the porcine respiratory epithelium as observed by electron microscopy. Infect. Immun. 37:1162-1169

ZIELINSKI, G. C., YOUNG, T., ROSS, R.F. 1990: Adherence of Mycoplasma hyopneumoniae to cell monolayers. Am. J. vet. Res. 51:339-343 
Plate XXIII.

Fischer O.: Enhancement... pp. 243-247.

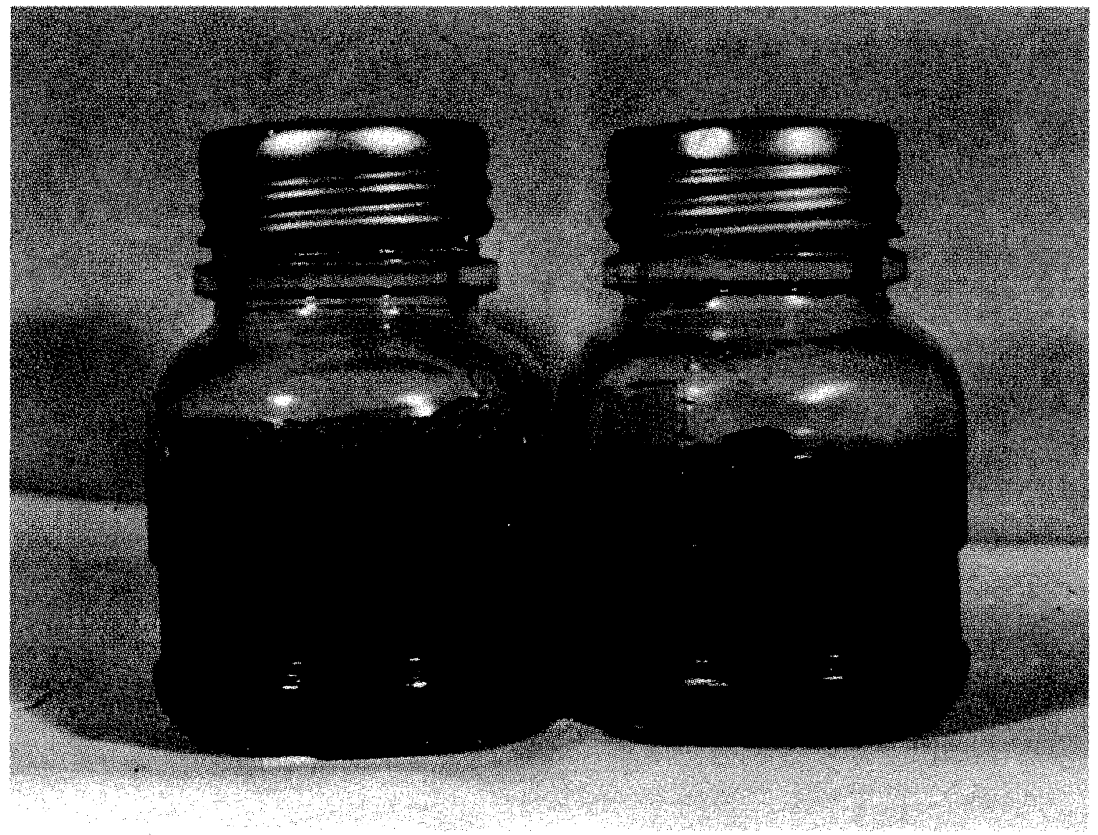

Fig. 1: Cultivation of Mycoplasma hyopneumoniae in liquid (A) and biphasic (B) media (experiment 1). 